http://nv.nltu.edu.ua

https://doi.org/10.36930/40291001

$@ \bowtie$ Correspondence author

Article received 05.11.2019 p.

Article accepted 26.12.2019 p.

G. T. Krynytskyy

удк 378:504:316

gt.krynytskyy@gmail.com

Ю. Ю. Туниця, М. Г. Адамовський, М. М. Борис, Г. Т. Криницький

Національний лісотехнічний університет України, м. Львів, Україна

\title{
НАЦІОНАЛЬНИЙ ЛІСОТЕХНІЧНИЙ УНІВЕРСИТЕТ УКРАЇНИ - ЛІДЕР ВІТЧИЗНЯНОЇ ОСВІТИ І НАУКИ В ДОСЯГНЕННІ ЦІЛЕЙ СТАЛОГО РОЗВИТКУ
}

Окреслено здобутки і роль Національного лісотехнічного університету України у царині екологізації вітчизняної освіти і науки. Доведено, що університет є провідним закладом вищої освіти у забезпеченні лісового господарства, деревообробної промисловості та суміжних галузей економіки України, який готує висококваліфікованих фахівців, спроможних вирішувати виробничо-господарські проблеми в контексті вимог сталого розвитку. Розглянуто сутність і сучасні проблеми екологізації вищої освіти з урахуванням глобальних екологічних викликів. Беручи до уваги 145 -літню історію університету, подано досягнення його колективу в підготовці фахівців і здійсненні фундаментальних та прикладних наукових досліджень 3 актуальних проблем соціо-еколого-економічного розвитку України, що дало змогу університету стати лідером вітчизняної освіти і науки у сфері пошуку шляхів досягнення цілей сталого розвитку. Обгрунтовано необхідність реалізації ідеї Екологічної Конституції Землі як міжнародного правового акта екологічної безпеки планети і сталого розвитку суспільства. Концепцію цього міжнародного Акта розробили науковці НЛТУ України під керівництвом академіка НАН України, професора Ю. Ю. Туниці.

Визначено стратегію та основні пріоритетні напрями досліджень сформованих в університеті наукових шкіл, зважаючи на те, що університет перебуває на перехідному етапі становлення від моделі університету розвитку до моделі підприємницько-екосистемного сучасного університету, активно інтегруючись у європейську та світову систему вищої освіти $\mathrm{i}$ науки. На підставі розробленої в університеті "Стратегії і перспективних напрямів розвитку освітньої, наукової та інноваційної діяльності" обгрунтовано засади виконання покладених на університет статутних функцій з формування патріотичної національно свідомої еліти України, підготовки висококваліфікованих фахівців для багатьох галузей вітчизняної економіки і сфер суспільного життя, подальшого розвитку лісотехнічної освіти і науки.

Ключові слова: екологізація освіти і науки; лісовий сектор економіки; сталий розвиток; екологічна компетентність; еколого-економічне мислення.

Національний лісотехнічний університет України (НЛТУ України) - єдиний в Україні навчально-науковий заклад лісотехнічного профілю. Він $є$ одним із найстаріших і престижних поліфункціональних вищих навчальних закладів. У 2018 р. НЛТУ України відзначив 145 років від дня заснування і 25 років 3 часу надання йому найвищого статусу - "університет".

Університет готує фахівців з усіх спеціальностей лісового сектору економіки України і проводить фундаментальні та прикладні наукові дослідження з актуальних галузевих та комплексних міжгалузевих проблем соціо-еколого-економічного розвитку України.

Інтегрувавшись у європейську та світову систему вищої освіти і науки завдяки наполегливій творчій праці співробітників та високому рівню підготовки фахівців, зробив вагомий внесок у розвиток лісового госпо-

дарства, лісової та деревообробної промисловості, а також суміжних галузей економіки, чим здобув широке міжнародне визнання. Завдяки екологізації освітнього процесу та формуванню еколого-економічної компетентності фахівців він об'єктивно став одним 3 лідерів вітчизняної освіти і науки у сфері пошуку шляхів досягнення цілей сталого розвитку.

Концепція так званої третьої місії сучасного підприємницького університету, яку запропонували Етцковіц і Кларк у 1998 р. (Etzkowitz, 1998; Clark, 1998), висунула перед закладами вищої освіти (ЗВО) України два завдання: перше - зробити внесок в економічний розвиток; друге - участь університетів у забезпеченні глобальної стійкості, виходячи з розуміння невідворотності глобальної соціальної та екологічної кризи (Mero, 2011). Сучасне розуміння місії вищої школи відріз-

\section{Інформація про авторів:}

Туниця Юрій Юрійович, д-р екон. наук, професор, академік НАН України, ректор. Email: nltu@ukr.net

Адамовський Микола Григорович, канд. техн. наук, професор, перший проректор з науково-педагогічної роботи. Email: nltu@ukr.net

Борис Микола Михайлович, канд. техн. наук, доцент, проректор з науково-педагогічної виховної роботи та міжнародних зв'язків. Email: borysmm@ukr.net

Криницький Григорій Томкович, д-р біол. наук, професор, завідувач кафедри лісівництва. Email: gt.krynytskyy@gmail.com Цитування за ДСтУ: Туниця Ю.Ю., Адамовський М. Г., Борис М. М., Криницький Г. Т. Національний лісотехнічний університет України - лідер вітчизняної освіти і науки в досягненні цілей сталого розвитку. Науковий вісник НлтУ України. 2019, т. 29, № 10. С. 09-17.

Citation APA: Tunytsya, Yu. Yu., Adamovskyy, M. G., Borys, M. M., \& Krynytskyy G. T. (2019). Ukrainian National Forestry University the leader of national education and science in achieving sustainable development goals. Scientific Bulletin of UNFU, 29(10), 09-17. https://doi.org/10.36930/40291001 
няється різноманітністю й багаторівневістю, пошуком університетом свого власного обличчя і власної моделі взаємовідносин з його стейкхолдерами у складному та мінливому світі (Krykunov, 2006).

Виходячи із розуміння місії вищої освіти, враховуючи впровадження інноваційних методів навчання, особливо екологізацію освіти, Національний лісотехнічний університет України - це відкритий, креативний, конкурентоздатний, соціально відповідальний навчально-науковий заклад із багатолітніми традиціями та визнаними науковими школами у поєднанні із сучасними інноваційними трендами, який ефективно виконує "третю місію" сучасного університету - забезпечує високу якість навчального процесу, готує висококваліфікованих і конкурентоспроможних на ринку праці фахівців, реалізує наукові дослідження; поглиблює інтеграцію університету в європейський та світовий освітній та науковий простір; створює умови для мобільності студентів та викладачів, залучення іноземних фахівців і студентів до навчального процесу; посилює роль університету в суспільстві та розвитку студентського самоврядування і громадського контролю, що базується на принципах самоорганізації університетської автономії, залучення працівників та студентів до прийняття рішень, забезпечує формування естетичних потреб і почуттів та сприяння повноцінному розвитку студентської молоді, зміцнення фізичного і духовного здоров'я, вироблення екологічної культури молодої людини, розуміння необхідності гармонії іï відносин з природою, утвердження у свідомості та почуттях особистості національно-патріотичних цінностей і переконань.

Сьогодні НЛТУ України шляхом формування трикутника "університет - держава - бізнес" перебуває на перехідному етапі від моделі університету розвитку до моделі підприємницько-екосистемного сучасного університету, який є невід'ємною складовою екосистеми інновацій: взаємно залежної множини освітніх інституцій, органів влади, бізнес-структур, власників капіталу, які поєднані як формальними, так і неформальними зв'язками.

Сьогодні в Національному лісотехнічному університеті України навчається близько 5000 студентів. На 32 кафедрах працюють 370 висококваліфікованих науково-педагогічних працівників, 3 яких 46 - докторів наук, професорів, 216 - кандидатів наук, доцентів. Серед них - академік Національної академії наук України, заслужені діячі науки і техніки України, заслужені працівники освіти України, лауреати Державних премій України.

Почесними докторами університету є всесвітньо відомі вчені та політики: Гельмут Коль, Ганс Ессманн, Ріхард Бруннер, Ганс Юрген Досс, Дітер Блюменвітц, Бастіан Кайзер, Вільгельм-Гюнтер Фарзон, П'єр Ібіш (ФРН), Леонід Рудницький, Юрій Солтис (США), Ноель Луст (Бельгія), Давіде Петтенелла (Італія), Маріан Веселовскі (Польща), Абдул-Азіз бін Алі Рашід Аль-
Нуаймі (Об'єднані Арабські Емірати), Іоан Васіле Абрудан (Румунія), Леонід Каденюк (Україна).

У структурі університету функціонують: Навчальнонаукові інститути - Лісового і садово-паркового господарства; Інженерної механіки, автоматизації та комп'ютерно-інтегрованих технологій; Деревообробних та комп'ютерних технологій і дизайну; Екологічної економіки і менеджменту; Центр дистанційного навчання та післядипломної освіти; науково-дослідна частина, у складі якої є 25 кафедральних, дві галузеві та одна міжгалузева науково-дослідні лабораторії; Науково-технічна бібліотека; Мала лісова академія; Закарпатський лісотехнічний коледж (м. Хуст); Технологічний коледж (м. Львів); Природничо-технічний ліцей (с. Крукеничі, Львівська область); Ботанічний сад загальнодержавного значення; Страдчівський навчально-виробничий лісокомбінат; природний заповідник "Розточчя"; Закарпатський навчально-науково-виробничий центр (м. Хуст); оздоровчо-спортивний табір "Лісотехнік" у с. Рибаківка на березі Чорного моря, лісоекологічні стаціонари у Шацьку, Моршині та Східниці.

Виходячи із твердження, що покликання кожного університету - готувати сучасних фахівців для служіння суспільству, Національний лісотехнічний університет України реалізує цю благородну місію, працюючи під гаслом "Ad naturam vivere discimus" - "Вчимося жити в гармонії з природою".

Національний лісотехнічний університет України посідає вагоме місце в системі національної освіти України, використовуючи ідеї В. Вернадського та працюючи на засадах екологічної спрямованості освіти і науки. Завдяки європейському проекту enareco за програмою Tempus-Tacis, який університет виконував у партнерстві з університетами міст Фрайбурга (ФРН), Гента (Бельгія) і Падови (Італія), а також динамічному зростанню академічної мобільності студентів та співробітників, університет поглиблює інтеграцію у європейську і світову освітню систему.

Сьогодні за своєю структурою, переліком рівнів підготовки фахівців (перший бакалаврський, другий магістерський, третій освітньо-науковий, четвертий науковий) та ступенів (бакалавр, магістр, доктор філософії, доктор наук), а також екологічною спрямованістю університет відповідає сучасним моделям університетів Європи. Університет відіграє важливу соціальну роль, виходить за межі викладання освітніх курсів та наукових досліджень і стає інституцією громадянського суспільства.

Плідна та напружена робота колективу університету отримує високу оцінку на національному і міжнародному рівнях. Свідченням цьому є високі місця, які посідає НЛТУ України серед закладів вищої освіти нашої держави у різноманітних академічних рейтингах. Зокрема, у рейтингу закладів вищої освіти "Топ-200 Україна" університет впродовж останніх років входить до переліку кращих університетів держави (таблиця).

Таблиця. Рейтинг НЛТУ України за оцінкою ЮНЕСКО

\begin{tabular}{|c|c|c|c|c|c|c|c|c|c|c|c|c|}
\hline \multirow[b]{2}{*}{ Категорія } & \multicolumn{12}{|c|}{ Місце за навчальними роками } \\
\hline & $\begin{array}{l}2007- \\
2008\end{array}$ & $\begin{array}{l}2008- \\
2009\end{array}$ & $\begin{array}{c}2009- \\
2010\end{array}$ & $\begin{array}{l}2010- \\
2011\end{array}$ & $\begin{array}{l}2011- \\
2012\end{array}$ & $\begin{array}{c}2012- \\
2013\end{array}$ & $\begin{array}{l}2013- \\
2014\end{array}$ & $\begin{array}{c}2014- \\
2015\end{array}$ & $\begin{array}{c}2015- \\
2016\end{array}$ & $\begin{array}{l}2016- \\
2017\end{array}$ & $\begin{array}{l}2017- \\
2018\end{array}$ & $\begin{array}{l}2018- \\
2019\end{array}$ \\
\hline Серед 200 ВНЗ України & 9 & 27 & 26 & 30 & 32 & 31 & 38 & 37 & 33 & 29 & 29 & 23 \\
\hline Серед 20 ВНЗ Львівщини & 1 & 2 & 2 & 3 & 3 & 3 & 3 & 3 & 3 & 3 & 3 & 3 \\
\hline
\end{tabular}


Сучасні тенденції суспільного розвитку України потребують переходу вищої освіти на нову концепцію підготовки майбутніх фахівців, удосконалення іiі якості, що вмотивовує процеси інтегрування, підвищення рівня професіоналізму, компетентності та інтелектуальної культури. Ключовою парадигмою сучасної освіти стає iii орієнтація на особистість, що вимагає докорінного оновлення і перебудови усталених методичних підходів. В умовах демократизації та гуманізації суспільства виникає потреба в появі нових вимог до особистіснопрофесійних якостей фахівців із вищою освітою. 3 огляду на це перед сучасною українською лісотехнічною освітою постало непросте завдання - зберегти усі позитивні здобутки та досвід національної освіти і збагатити його інноваційними досягненнями європейських освітніх середовищ.

В університеті ведуть пошук альтернативних моделей організації вищої освіти, апробації та впровадження інноваційних педагогічних систем, реальних можливостей модернізації змісту освіти й організації її адекватно до світових тенденцій і вимог ринку праці, а також забезпечення безперервності освіти та навчання впродовж усього життя.

Національний лісотехнічний університет України має великий досвід з модернізації змісту вищої лісотехнічної освіти. У 1993 р. університет було включено Мiністерством освіти і науки України (МОН України) в експериментальну групу із шести 3ВО України для апробації впровадження ступеневої системи освіти: бакалавр - спеціаліст - магістр. У цей же період було розроблено, затверджено МОН України та впроваджено в університеті інтегровані навчальні плани 3 підготовки фахівців (на базі ОКР молодший спеціаліст) зі скороченим терміном навчання. Упродовж двох десятиліть науково-педагогічні працівники університету, відповідно до наказів МОН України, розробили п'ять (1995 р., 1998 р., 2005 р., 2013 р., 2018 р.) варіантів державних стандартів вищої освіти за спеціальностями лісотехнічного профілю для підготовки бакалаврів, спеціалістів і магістрів.

Вагомих результатів досягнуто НЛТУ України в питаннях екологізації освітнього процесу. Університетом започатковано і набуто значного досвіду з розроблення програм екологізації підготовки фахівців різних спеціальностей, запровадження нових сучасних магістерських програм підготовки фахівців з екологобезпечних та ресурсоощадних технологій, 3 економіки довкілля й природних ресурсів, а також проведення системних наукових досліджень, виховних і просвітницьких заходів, спрямованих на формування екологічної свідомості та екологічної культури студентів (Tunytsia et al., 2015; Tunytsia, Zahvoiska, \& Adamovskyi, 2016).

Національним лісотехнічним університетом України разом із Національним технічним університетом України "Київський політехнічний інститут" ініційовано обговорення питання екологізації національної освіти на сучасному етапі на Колегії Міністерства освіти і науки України. За його результатами було прийнято Piшення від 27 листопада 2015 року "Про екологізацію вищої освіти України з метою підготовки фахівців для сталого розвитку" (Rishennia Kolehii, 2015). У цьому документі означено набутий низкою ЗВО України досвід здійснення екологізації освіти 3 метою підготовки фахівців для сталого розвитку, який може стати підгрунтям для здійснення реформування системи освіти в державі.

Введення за ініціативи НЛТУ України екологічної компетентності до державних стандартів освіти, починаючи 3 початкової і завершуючи вищою, стало важливим етапом розв'язання однієї з освітніх проблем - забезпечення практичної реалізації тріади "екологічне виховання - екологічне навчання - екологічна освіта". Усі складники цієї тріади $\epsilon$ взаємопов'язаними та сприяють формуванню у людини екологічного світогляду, що базується на усвідомленні необхідності збереження оптимального для життя середовища.

Процес структурного реформування національної лісотехнічної освіти, розроблення й удосконалення освітньо-професійних і освітньо-наукових програм, а також процес інституційних перетворень відбувається за такими головними напрямами: прийняття зручних та зрозумілих назв освітніх програм; впровадження Європейської системи кредитних одиниць (СКТС); розроблення та дотримання стандартів вищої освіти, а також європейських стандартів якості освітніх послуг; створення необхідних умов для активізації академічної мобільності студентів, науково-педагогічних та наукових працівників.

Під час розроблення нових та удосконалення наявних освітньо-професійних програм їх розробники керувалися тим, що одним із провідних напрямів перебудови освітньої системи $є$ перехід від концепції підтримуючого навчання до концепції випереджувального навчання. Сьогодні принципи практичної реалізації такого переходу є відчутними під час розроблення освітньопрофесійних програм підготовки бакалаврів і магістрів за всіма спеціальностями університету з урахуванням сучасних вимог ринку праці.

Випереджувальне навчання $\epsilon$ орієнтованим на майбутнє, тобто на ті умови життя та професійної діяльності, у яких випускник 3ВО опиниться після його закінчення. Такий підхід $є$ надзвичайно актуальним, оскільки, як відомо, значна частина знань старіє уже впродовж 3-5 років. Тому головна увага в навчальному процесі за такою концепцією зосереджена на розвитку творчих якостей фахівця, його здатностях до самостійних дій в умовах невизначеності, а також на розвитку здібностей до набуття нових знань та навичок, оволодіння сучасними методами отримання, накопичення, класифікації та передачі знань.

У системі випереджувального навчання основну частку навчального часу відводять на засвоєння нових фундаментальних знань, процесів та технологій, інформація про які надходить в освітню систему різними каналами взаємодії з системою науки і банками даних науково-технічної інформації. Тому важливою умовою реалізації системи випереджувальної освіти є їі тісний зв'язок з наукою. Освіта повинна бути "вмонтованою" в систему наукових досліджень.

У вітчизняному і світовому вимірі Національний лісотехнічний університет України в процесі свого розвитку утвердився як дослідницький університет екологічного спрямування. Стратегію та основні пріоритетні напрями досліджень визначають історично сформовані в університеті такі наукові школи:

- $з$ лісівничо-екологічних проблем підвищення продуктивності та біотичної стійкості лісових екосистем; 
• з еколого-економічних проблем сталого лісокористування i охорони довкілля;

- $з$ екологобезпечних і ресурсоощадних технологій лісозаготівлі та транспортування деревини;

• $з$ проблем підвищення ресурсу роботи деталей машин, дереворізальних інструментів і технологічного оснащення;

- 3 екологобезпечних та енергоощадних технологій виготовлення деревинних композиційних матеріалів та сушіння деревини.

У цих напрямах науковці університету мають вагомі інноваційні напрацювання 3:

- біо- і нанотехнологій;

- реформування лісового господарства;

- виявлення еколого-економічних механізмів та інструментів сталого природокористування;

- розроблення нових охороноздатних деревинних композиційних матеріалів теплової, захисного оброблення та сушіння деревини;

• виготовлення дереворізальних і великогабаритних абразивних інструментів та зміцнення деталей машин і технологічного оснащення;

• розроблення апаратури для неруйнівного контролю якості промислових виробів.

Університет своїми науковими здобутками значною мірою формує лісову політику України, впливає на розвиток лісового господарства, лісопромислової та деревообробної галузей. Зокрема, в контексті реформування лісового господарства розроблено способи і технології переформування деревостанів та поступового переходу від панівної на цей час суцільно-лісосічної системи господарювання, яка є неприйнятною з екологічних міркувань і негативно сприймається суспільством, до вибіркової, наближеної до природи, за якої відсутні суцільні зруби, а ліс постійно та ефективно виконує екологічні функції і одночасно повністю задовольняє соціальні та економічні потреби суспільства в лісових ресурсах.

Особливо актуальною ця проблема є в сучасний період, коли антропогенний негативний вплив дедалі частіше досягає критичних значень. У сучасних умовах орієнтація на відновлення лісостанів переважно природним насіннєвим шляхом i вирощування мішаних різновікових лісів стає необхідністю. Лише на цих лісівничих засадах можливе формування біотично стійких насаджень, збереження біорізноманіття, стале лісокористування і постійне (безперервне) виконання лісом корисних середовищетвірних, рекреаційних, захисних, оздоровчих та інших суспільно значущих функцій. Отримані університетом результати досліджень у цьому напрямку підтримано Львівською обласною радою і взято до розгляду Державним агентством лісових ресурсів України.

Реформування лісового господарства на засадах наближеного до природи лісівництва тісно пов'язане 3 еколого-економічним вченням щодо організації сталого лісокористування і охорони довкілля, підгрунтя якого заклав ще у 70-80-х роках ХХ ст. академік НАН України, доктор економічних наук, професор Ю. Ю. Туниця.

Основні положення еколого-економічної теорії викладено у його монографії "Еколого-економічна ефективність природокористування" (1980), яку було визнано внеском СРСР у міжнародну програму ЮНЕСКО "Людина і біосфера". На основі принципів еколого-економічного оцінювання лісових ресурсів сформульовано сутність еколого-економічного вчення, яке на противагу традиційній ринковій чи командно-адміністративній економіці, має на меті розроблення ефективних методів урахування екологічних факторів в економічних системах як їх організаційних складових. У сучасний період небувалого загострення екологічної ситуації та зростання антропогенного навантаження на природні екосистеми, розроблення науково-методичних засад переходу на принципи еколого-економічного природокористування - основи сталого розвитку і держави $є$ надзвичайно актуальним як у регіональному, так і у глобальному виmipax.

Для реалізації цього переходу дуже важливою є підготовка нового типу фахівців - економістів-екологів. 3 цією метою вчені університету визначили світоглядні, методологічні та дидактичні передумови, виявили особливості екологізації освіти та основні чинники оптимізації освітньої діяльності університетів на засадах сталого розвитку.

Опрацьована в університеті екологізація освітніх програм підготовки здобувачів вищої освіти покликана забезпечити збагачення знань і світогляду кожного фахівця глибоким розумінням причинно-наслідкових взаємозв'язків і залежностей між діяльністю людини та станом природного життєвого середовища. Кожен фахівець має оволодіти новим еколого-економічним мисленням для забезпечення гармонізації екологічних та економічних інтересів суспільства і його сталого розвитку.

Водночас для реалізації глобальної стратегії сталого розвитку і екологічної безпеки на Землі необхідне розроблення відповідних законодавчих основ та запровадження правових норм обов'язкового їх виконання усіма державами світу, всім світовим співтовариством. 3 цією метою академік НАН України, професор Ю. Ю. Туниця вперше виголосив ідею і розробив концепцію Екологічної Конституції Землі (ЕКЗ) - міжнародного правового акта екологічної безпеки планети i сталого розвитку суспільства. Конституція повинна визначити допустимі норми екологічної діяльності держав стосовно єдиної екосистеми Землі для їі раціонального використання в інтересах нинішнього покоління i збереження для майбутніх поколінь.

Концепція ЕКЗ передбачає також створення у системі ООН відповідних контролюючих органів за дотриманням встановлених норм господарської діяльності національних і міжнародних структур. Такими органами могли би стати: Рада екологічної безпеки, Світова екологічна організація, Міжнародна екологічна поліція, Міжнародний екологічний суд, Світовий екологічний банк або Глобальний екологічний фонд та інші структури.

Ідею створення і прийняття міжнародною спільнотою Екологічної Конституції Землі було офіційно задекларовано президентами України в Організації Об'єднаних Націй (1997, 2008, 2009, 2011 рр.) та на Світовому Саміті "Ріо+20" (2012 р.). У сучасних екологічних умовах визнання ідеї, розроблення та прийняття ЕКЗ набуває особливої гостроти з огляду на ратифікацію більшістю держав світу Паризької угоди 3 кліматичних змін (2015 p.).

Потрібно зазначити, що активна наукова робота розпочалася в інституті (нині - Національний лісотехнічний університет України) з перших років його створення. Уже в перші навчальні роки ректорат і колективи кафедр визначили тематику науково-дослідних робіт, спрямовану на вирішення актуальних завдань щодо під- 
вищення продуктивності та біотичної стійкості лісів, раціонального ведення лісового господарства, підвищення продуктивності праці в лісовому комплексі, зниження собівартості продукції на лісозаготівлях, здешевлення перевезення та перероблення деревини, поліпшення іiі якості, виготовлення з неї виробів та використання їх у різних сферах національного господарства.

Упродовж 50-70-х років XX ст. науковці інституту отримали вагомі наукові результати під час виконання таких завдань:

- проходження відновних процесів в основних типах лісу, формування високопродуктивних і біотично стійких деревостанів;

- вирощування швидкорослих цінних порід - псевдотсуги Мензіса, ялиці великої, модрин європейської і японської, сосни Веймутова, дуба червоного, берези повислої та інших;

- виникнення епіфітотій та підвищення стійкості лісостанів проти грибкових захворювань та поширення ентомошкідників;

- опрацювання дендрохронологічних шкал і складання багатовікових шкал росту деревних порід;

- створення лісових культур без попереднього обробітку грунту та подальшого догляду за молодими насадженнями;

- вивчення сокопродуктивності та технологічних процесів підсочки листяних порід;

- визначення життєвості деревних рослин електрофізіологічними методами;

- реконструкція урбанізованих зелених насаджень, парків скверів, зокрема Стрийського парку та парку імені Івана Франка у Львові, Софіївського парку в Умані;

- способи збільшення і раціонального використання харчових, лікарських і технічних недеревних компонентів лісових екосистем;

- вплив радіаційного опромінювання в Чорнобильській зоні на ріст лісових насаджень, їх плодоношення (насіннєношення) та ріст і розвиток потомства;

- економічні аспекти управління та організації виробництва у лісогосподарській та деревообробній галузях;

- проведення лісоексплуатаційних робіт у гірських умовах;

- удосконалення технологічних процесів експлуатації вузькоколійних залізниць;

- конструювання підвісних линвових лісотранспортних систем, удосконалення канатного транспорту, збільшення міцності та довговічності линв, виявлення раціональних режимів експлуатації линвового обладнання під час первинного транспортування деревини;

- зміцнення зносостійкості інструментів та деталей машин способом віброоброблення та пластичного деформування оброблювальних поверхонь;

- конструювання буферних пристроїв і виявлення механізмів живлення автоматизованих ліній лісопромислових підприємств та запровадження ефективних технологій механізації та автоматизації виробничих процесів;

- автоматизоване керування верстатами з оброблення складних криволінійних поверхонь.

Учені університету розробили великогабаритні абразивні інструменти для калібрування-шліфування деревини та деревинних матеріалів, які не мають аналогів у світовій практиці шліфування (проф. А. І. Яцюк, ст. наук. співроб. О. Я. Густі), інноваційні паркетні вироби орнаментальних композицій 3 функціональними властивостями типу "кондиціонер природної дії" (проф. В. В. Шостак, ст. наук. співроб. П. П. Онуфрик), експериментальні біогазові установки для отримання нових альтернативних джерел енергії (доц. І. Г. Войтович), екологічно чисті технології сушіння деревини та дере- винних матеріалів (доц. І. А. Стріха, проф. П. В. Білей, проф. І. М. Озарків), експериментальні зразки підвісних канатних систем лісозаготівельного та рекреаційного призначення (проф. Н. М. Белая, проф. М. Г. Адамовський, проф. М. П. Мартинців, доц. Е. М. Матвеєв, доц. Я. О. Лико), високоефективні дефектоскопи і товщиноміри для неруйнівного контролю якості промислових виробів (доц. Ж. О. Ямпольський, доц. І. Р. Кенс, ст. наук. співроб. М. С. Маруняк, ст. наук. співроб. А. М. Єрмаков, ст. наук. співроб. О. Г. Алещенко), проекти напівавтоматичних ліній розколювання і складання низькосортної деревини та причепний гідроколун (проф. Т. М. Шкіря), верстат для шліфування фанерних деталей меблів (доц. К. С. Худін), вологомір "ВЕБ-2", рекомендований урядовими інстанціями для державних випробувань і масового випуску (доц. М. Я. Броун), ланцюгові кулачкові пристрої для розбирання пачок колод і їх поштучного видавання (проф. І. В. Батін), циліндричні гвинтові фрези для звалювально-пакетувальних машин (проф. А. Н. Тинний), автоматичний маятниковий верстат для шліфування криволінійних поверхонь (проф. І. В. Батін, інж. А. А. Береніс, інж. Є. О. Геврик), технологія виготовлення облицювальної фанери (доц. О. І. Янсон) та інші напрацювання.

У 60-х роках ХХ ст. науковці університету під керівництвом професора М. М. Горшеніна для гірських умов Карпат розробили новий спосіб рубок головного користування - механізовані улоговинні, що поєднує короткотермінові та дрібнолісосічні рубки. Спосіб забезпечує комплексну механізацію лісосічних робіт, значне зменшення ерозійних процесів, надійне природне поновлення деревостанів та збереження підросту на зрубах.

У другій половині 90-х років науковці університету розробили теоретичні засади лісової політики, а впродовж наступних років обгрунтували іiі принципи та інструменти. Результати цих досліджень лягли в основу проектів "Лісового кодексу України" та Закону України "Національна лісова політика".

Зроблено певний внесок у вирішення фундаментальної проблеми, якою $є$ розшифровка генної структурної організації геномів живих організмів. Науковці університету в лабораторії молекулярно-генетичних маркерів деревних рослин виділили нові гени білків-дефензинів і ліпід-трансферних протеїнів, які зумовлюють біологічну стійкість дерев проти ураження фітохворобами. Нуклеотидні послідовності генів цих білків зареєстровано у Світовому банку генів (Вашингтон, США). Отримані результати мають не тільки вагоме теоретичне значення для визначення геномної організації деревних рослин, але і конкретне практичне значення. Виділено окремі гени білків-дефензинів, які зумовлюють реакцію-відповідь дерев на ураження фітопатогенами, і розробляють способи активації роботи цих генів. Для хвойних рослин такі результати у світовій практиці отримано вперше.

Науковці університету модифікували на нанорівні полімерні матеріали природного та синтетичного походження й отримали нові металоорганічні сполуки у взаємодії з деревинною целюлозою. Загалом зроблено вагомий вклад у розвиток кристалічної інженерії та в мало вивчену кристалохімію комплексних металоорганічних сполук. Структурну інформацію про досліджені полімерні комплекси передано в банк комплексних сполук (CCDC Кембрідж, Англія). 
Вагомі наукові результати отримують також аспіранти, докторанти та здобувачі наукових ступенів під час підготовки кандидатських і докторських дисертацій. В університеті діють аспірантура, докторантура i три спеціалізовані вчені ради із захисту докторських і кандидатських дисертацій з восьми наукових спеціальностей, на яких захищено понад 150 кандидатських i 30 докторських дисертацій. Науковці університету щорічно видають монографії, навчальні посібники, підручники, а також публікують статті у вітчизняних і зарубіжних виданнях, які входять до наукометричних баз Scopus i Web of Science та інші, отримують охоронні документи на об'єкти інтелектуальної власності.

Університет відомий в Україні та за рубежем як видавничий центр: регулярно забезпечує випуск трьох наукових видань, зокрема збірника науково-технічних праць "Науковий вісник НЛТУ України" та збірників наукових праць "Forestry, Forest, Paper and Woodworking Industry" i "Наукові праці Лісівничої академії наук України", які є фаховими виданнями, входять до наукометричної бази Copernicus i мають міжнародний цифровий ідентифікатор об'єкта (індекс DOI). Проводять організаційні заходи для включення цих наукових видань до наукометричної бази Scopus.

Університет успішно впроваджує у виробництво результати наукових досліджень. Зокрема, з проблем переформування одновікових деревостанів у різновікові складної просторової структури на основі природного поновлення, підготовки фітоценотичних матеріалів для створення об'єктів природно-заповідного фонду, інвентаризації зелених насаджень, ландшафтного облаштування і благоустрою населених місць, проведення комплексних лісогосподарських та інженерно-екологічних експертиз, виготовлення електроіскрових дефектоскопів, розроблення абразивних циліндрів для калібрування деревинно-стружкових плит.

Університетом закладено десятки науково-виробничих стаціонарів з відпрацювання технологій і способів рубок головного користування 3 врахуванням регіональних особливостей, догляду за лісостанами, переформуванням одновікових деревостанів у різновікові на основі природного поновлення для організації вибіркової системи лісогосподарювання тощо. У 1984 р. у Страдчівському навчально-виробничому лісокомбінаті університету закладено географічні культури сосни звичайної, які мають 32 повторності, а в 1995 р. на виконання загальноєвропейської програми створено географічні культури бука лісового за участю 70 географічних варіантів з різних європейських країн.

Національний лісотехнічний університет України володіє значним науковим потенціалом, реалізація якого дасть змогу отримати нові вагомі фундаментальні та прикладні результати зі структурно-функціональної організації лісових екосистем і лісокористування, розроблення нових технологій для лісової і деревообробної промисловості.

Національний лісотехнічний університет України активний учасник міжнародної діяльності як член низки авторитетних міжнародних організацій: Міжнародної спілки лісових дослідницьких організацій (International Union of Forest Research Organisations, IUFRO, 3 1994 р.), Академічної асоціації європейських лісових університетів (Academic Network of European Universiti- es, SILVA Network, 31999 р.), Ради Європейських Лісівників CEF (з 2012 р.).

Університет співпрацює 3 низкою інституцій і мереж, таких як Council of European Foresters, IFSA (International Association of Student Foresters), WWF (World Wildlife Fund), FSC (Forest Stewardship council), COST (European cooperation in scientific and technical research). Участь у цих організаціях сприяє поширенню інформації про українську лісову освіту і науку, взаємному обміну досвідом і встановленню особистих контактів між науковцями різних країн, а також піднімає авторитет університету та України загалом на європейському i світовому рівнях.

Міжнародне наукове та науково-технічне співробітництво університету здійснюється в таких напрямках: стале лісокористування, ведення лісового господарства на засадах наближеного до природи лісівництва, підвищення стійкості вразливих лісових екосистем в умовах змін довкілля, використання недеревних ресурсів лісу, лісовий менеджмент, екологічна економіка, економіка та менеджмент лісових підприємств, технології деревообробки, технології виробів 3 деревини.

Наймасштабнішим прикладом міжнародної співпраці університету залишаються проекти за програмою Європейського Союзу TEMPUS TACIS (1995-2002рp.), які реалізовували у партнерстві 3 університетами Фрайбурга (Федеративна Республіка Німеччина), Падуї (Італійська Республіка) і Гента (Королівство Бельгія), що дали поштовх розвитку освітньої програми та наукових досліджень в галузі економіки довкілля і природних ресурсів. Загальний обсяг фінансування цих проектів становив близько 1,5 млн дол. США.

Його результатом стало впровадження в Україні нової спеціальності на магістерському рівні за кваліфікацією "економіст-еколог". Перший експериментальний випуск магістрів за цією кваліфікацією відбувся у Львові в 2000 р. На сьогодні 16 університетів України готують фахівців за цією надзвичайно важливою для національної економіки і перспективною у міжнародному вимірі спеціальністю.

Упродовж останніх років розширилися можливості українських університетів щодо участі у міжнародних проектах завдяки істотному збільшенню обсягів фінансування за європейськими програмами та отриманню Україною рівноправного з європейськими партнерами статусу в Рамковій програмі Свропейського Союзу 3 досліджень та інновацій "Горизонт - 2020", а також програмою Європейського Союзу з академічної мобільності Еразмус+. Це сприяло процесу інтернаціоналізації університету, позитивним кількісним і якісним змінам у його міжнародній діяльності.

На основі позитивних тенденцій співпраці у міжнародному аспекті активізувалася робота також в університеті. У 2015 р. Вчена рада НЛТУ України схвалила "Стратегію міжнародної діяльності Національного лісотехнічного університету України на період до 2020 року в контексті інтернаціоналізації вищої освіти України", яка вперше зафіксувала стратегічні цілі, принципи, пріоритети і ключові показники міжнародної діяльності. НЛТУ України розглядає міжнародну співпрацю загалом та інтегрування в європейський освітній і науковий простір як пріоритетний напрям у всіх аспектах діяльності університету, прагне досягти міжнародних стандартів освітньої, дослідницької та адміністративної 
діяльності, зміцнити дослідницько-інноваційний потенціал, стати привабливішим для вітчизняних та зарубіжних замовників освітніх і наукових послуг, а також для партнерів.

Задля досягнення поставлених Стратегією цілей докладають багато зусиль: запроваджено нові процедури адміністрування міжнародної діяльності, на всіх рівнях ведеться активна робота із зарубіжними партнерами, спрямована на входження університету до нових міжнародних проектів, підвищується кваліфікація науково-педагогічних та адміністративних працівників 3 питань інтернаціоналізації шляхом міжнародних навчань і стажувань.

На сьогодні НЛТУ України уклав 65 міжнародних угод 3 освітніми закладами і науковими установами практично $з$ усіх континентів світу, співпраця з якими 3 кожним роком поглиблюється і набуває нових форм та змісту.

Основними напрямками міжнародної співпраці НЛТУ України є наукові дослідження в рамках дослідницьких мереж за програмою ЄC COST Actions (20092019 рр.) і виконання грантових угод та проектів в рамках Програми ЄС "Горизонт - 2020", академічні обміни за напрямом КА1 програми СС Еразмус+, освітні проекти за програмами Британської Ради в Україні, діяльність за Програмою Балтійського Університету та співробітництво зі стратегічними партнерами, такими як: Університет сталого розвитку м. Еберсвальде (ФРН), Трансільванський університет м. Брашова (Румунія), Університет прикладних лісових наук м. Ротенбурга (ФРН), Університет м. Вальядоліда (Іспанія), Технічний університет м. Зволена (Словаччина), Університет ім. Менделя у м. Брно (Чеська Республіка), Познанський університет наук про життя (Республіка Польща), Інститут Джеймса Хаттона (Сполучене Королівство Великої Британії та Північної Ірландії) та інші.

Завдяки участі НЛТУ України в проектах академічної мобільності за програмою Євросоюзу Еразмус+ (напрям КА1) студенти університету отримали змогу навчатися в зарубіжних університетах із здобуттям кредитів Свропейської кредитно-трансферної системи ECTS, а аспіранти, наукові та науково-педагогічні працівники - стажуватися у провідних зарубіжних закладах вищої освіти та наукових установах.

Найактивніше реалізовується академічна мобільність 3 такими зарубіжними партнерами: Університет сталого розвитку м. Еберсвальде (Німеччина), Трансільванський університет м. Брашова (Румунія), Технічний університет м. Зволена (Словаччина), Естонський університет природничих наук м. Тарту (Естонія), Вища школа туризму i екології м. Суха Бескидська (Польська Республіка), Познанський університет природничих наук (Польська Республіка), Лодзька політехніка (Польська Республіка), Університет Любляни (Словенія) та Університет Вальядоліду (Іспанія).

Пріоритетом академічної мобільності науково-педагогічних працівників університету $є$ розроблення навчальних дисциплін іноземними мовами, що дозволило ліцензувати одинадцять спеціальностей на право здійснювати підготовку іноземців та осіб без громадянства, і дає змогу відкривати спільні із зарубіжними університетами-партнерами міжнародні освітні програми.
Розвивається і вхідна мобільність науково-педагогічних працівників та студентів зарубіжних університетів-партнерів.

Важливою складовою частиною навчально-виховного процесу є національно-патріотичне виховання студентів університету. В НЛТУ України сформувалася i діє система національно-патріотичного виховання, яка покликана забезпечувати становлення самодостатнього громадянина - патріота України, гуманіста і демократа, готового до виконання своїх громадянських обов'язків.

Сьогодні в університеті, зберігаючи традиції виховної роботи, на підставі системного підходу, органічно впроваджена єдина політика навчання і виховання, яка реалізується Системою національно-патріотичного виховання студентів НЛТУ України. Ця Система відображає принципи, мету і завдання "Концепції національнопатріотичного виховання дітей та молоді", що реалізується в Україні.

Робота 3 виховання студентів університету здійснюється шляхом проведення різноманітних заходів інститутами та кафедрами, Народним домом і науково-технічною бібліотекою. Важливу роль відіграють кафедри гуманітарно-соціальних дисциплін, які комплексно охоплюють навчальний і позанавчальний процес, впроваджують нові технології організації виховної роботи. До неї активно долучаються Студентська рада i профком студентів.

Питання виховної роботи студентів університету систематично розглядають на засіданнях Координаційної ради кафедр гуманітарно-соціальних дисциплін, Ради університету з виховної роботи, Вчених рад університету та навчально-наукових інститутів і методичних семінарах. На підставі їх розгляду визначають шляхи покращення виховної роботи в університеті.

В університеті велику увагу надають екологічному вихованню, основним завданням якого $є$ формування основ глобального екологічного мислення та екологічної культури студентів, виховання почуття відповідальності за природу як національне багатство, що стало невід'ємною частиною навчально-виховного процесу.

Перший Львівський Екологічний форум "Міста та місцеві громади: роль у вирішенні глобальних екологічних проблем", що відбувся у стінах університету, став визнанням важливості роботи, яку проводить колектив університету з питань екологізації освіти, проблем сталого розвитку та національно-патріотичного виховання студентів.

У цей складний для держави час, враховуючи агресію Росії, головним і пріоритетним напрямком в національно-патріотичному вихованні стало військово-патріотичне виховання студентів. Воно зорієнтоване на формування у студентів високого ідеалу служіння українському народові, готовності у будь-який момент стати на захист суверенітету і територіальної цілісності нашої держави.

У духовно-патріотичному вихованні студентської молоді особливу роль відіграє Студентський храм рівноапостольного князя Володимира, настоятель якого систематично організовує поїздки та прощі до святих місць, у яких беруть активну участь студенти університету, а також інші заходи. За ці роки храм став осередком для забезпечення духовних потреб студентів. При храмі утворена спільнота "Життя", яка допомагає дітям- 
сиротам, а також бійцям АТО, які лікуються в госпіталях Львова.

Навчально-наукові інститути університету разом із профспілковою організацією студентів НЛТУ України традиційно проводять щорічні фестивалі-конкурси художньої самодіяльності "День Першокурсника" в рамках фестивалю "Золота Осінь", а також фестиваль студентської творчості НЛТУ України "Весна Лісотехніки".

У духовному і патріотичному вихованні студентів чимала роль належить Народному дому, який свою роботу спрямовує на проведення різноманітних культурних заходів та залучення молоді до участі у гуртках художньої самодіяльності. У Народному домі функціонують Народна хорова капела "Діброва" і Народний ансамбль танцю "Полонина", які є візитівкою університету, а також студія художнього слова.

Заслуговує на увагу робота правничого студентського лекторію "Молодь і закон". Активно працює психолого-педагогічний семінар наставників академічних груп, робота якого спрямована на опрацювання психологічних проблем, які виникають в процесі педагогічної діяльності, обмін педагогічним досвідом, дискусійне обговорення актуальних проблем у діяльності викладачів-наставників.

Упродовж багатьох років активно й ефективно працює створений на кафедрі соціології та культурології Громадський центр соціологічних досліджень, який здійснює роботу за такими основними напрямами:

- дослідження мотивації абітурієнтів щодо вибору для навчання нашого університету та оцінка ефективності профорієнтаційної роботи викладачів та адміністрації університету;

- дослідження рівня екологічної культури студентів та співробітників університету;

- дослідження рівня задоволеності навчанням студентів, які завершують навчання на освітньому рівні бакалавр.

Культурно-просвітницька робота науково-технічної бібліотеки університету є складовою частиною національно-патріотичного виховання студентів НЛТУ України. Університетська бібліотека стає своєрідним центром інформування користувачів про події в зоні АТО і OOC, експонування найсвіжіших матеріалів 3 патріотичної тематики на тематичних поличках та книжкових виставках.

В університеті розроблено "Стратегію і перспективні напрями розвитку освітньої, наукової та інноваційної діяльності ДВНЗ "Національний лісотехнічний університет України", де окреслено засади виконання покладених на університет статутних функцій 3 формування патріотичної національної еліти України, підготовки висококваліфікованих фахівців для лісового господарства, лісопромислової, деревообробної та пов'язаних 3 ними суміжних галузей економіки і сфер суспільного життя, розвитку лісотехнічної науки. Цей документ ставить за мету вибудувати нову багатовекторну стратегію розвитку за напрямами життєдіяльності університету i забезпечити їі дієвими механізмами реалізації.

Стратегію розроблено з метою забезпечення якісних і кількісних перетворень в НЛТУ України для набуття повноцінних характеристик статусу національного університету, як одного $з$ вітчизняних лідерів освіти і науки, що сприятиме самореалізації студентів, науковопедагогічних працівників університету, формуванню соціально зрілої творчої особистості, громадянина України і світу, підготовці студентської молоді до сучас- ного ринку праці, який вимагає від випускника не лише глибоких теоретичних знань, а й здатності самостійно застосовувати їх у нестандартних постійно змінюваних життєвих ситуаціях, переходу від суспільства знань до суспільства життєво компетентних громадян.

Своє призначення університет реалізовує через:

- провадження на високому рівні освітянської та наукової діяльності на основі збалансованих і розроблених з урахуванням передового світового досвіду та принципів сталого розвитку освітньо-професійних (бакалаврських, магістерських), освітньо-наукових (магістерських, докторів філософіï) та наукових (докторів наук) програм;

- орієнтацію на оригінальні авторські програми вибіркових дисциплін;

- формування та впровадження інформаційного освітньо-наукового середовища і застосування в навчально-виховному і науково-дослідному процесі та бібліотечній справі, поряд iз традиційними засобами, інформаційно-комунікаційних технологій, а також доступу до світових інформаційних ресурсів;

- поєднання освітньої діяльності з науково-дослідною роботою;

- впровадження дистанційної форми навчання;

- розроблення та впровадження стандартів вищої освіти, зорієнтованих на компетентнісний підхід, узгоджених із новою структурою рівнів та ступенів вищої освіти і Національною рамкою кваліфікацій;

- залучення студентської молоді до проведення наукових досліджень і виконання наукових проектів, підготовки наукових робіт для участі у студентських конкурсах;

• посилення мовної, екологічної, економічної, правової підготовки студентів;

- розвиток системи профорієнтації, спрямованої на відбір обдарованої молоді для навчання у ЗВО з урахуванням демографічних і соціально-економічних умов держави;

- побудову ефективної системи національного виховання на засадах загальнолюдських, полікультурних, громадянських цінностей, забезпечення фізичного, морально-духовного розвитку студентів.

Удосконалюється і впроваджується нова модель освітньо-виховної діяльності, підсилюється рівень математичної і природничої підготовки фахівців. Отримання глибокої фундаментальної освіти дає змогу випускникам університету відповідати вимогам, встановлених рівнями, ступенями та кваліфікацією вищої освіти і Національною рамкою кваліфікацій. Важливим досягненням функціонування цієї моделі буде досягнення наскрізної інтегрованої підготовки здобувачів вищої освіти за ступенями бакалавр - магістр - доктор філософії.

Для реалізації такої підготовки впроваджуються прогресивні технології наукоємного інноваційного навчання, звертається особлива увага на екологізацію вищої освіти з метою підготовки фахівців для сталого розвитку, поглиблюється інтеграція з ринком праці, покращується науково-методичне, матеріально-технічне і фінансове забезпечення університетської діяльності.

Для ефективного проведення наукових досліджень і реалізації їх результатів у виробництво здійснюється планомірне відпрацювання нових форм організації наукової, науково-технічної та інноваційної діяльності в рамках дослідницького центру університету інноваційного типу: кафедри $\rightarrow$ кафедральні науково-дослідні лабораторії $\rightarrow$ держбюджетні та господарські науководослідні групи й тимчасові творчі колективи $\rightarrow$ наукові школи $\rightarrow$ державні ключові лабораторії з відповідного напрямку досліджень $\rightarrow$ галузеві, міжгалузеві науководослідні лабораторії $\rightarrow$ дільниці з випуску дослідних 
зразків науково-технічної продукції $\rightarrow$ бізнес-центр $\rightarrow$ малі інноваційні підприємницькі форми (стартапи).

Стратегією освітянської наукової діяльності НЛТУ України була і залишається підготовка висококваліфікованих фахівців для сталого розвитку, передусім лісового сектору економіки України. Науково-педагогічні працівники університету працюють над підвищенням ефективності та якості навчального, наукового і виховного процесу, удосконаленням змісту вищої лісотехнічної освіти та наукових досліджень, покращенням якості освіти, зокрема, екологічної компетентності випускників та їх конкурентоспроможності на ринку праці.

\section{References}

Clark, B. (1998). Creating Entrepreneurial Universities: Organizational Pathways of Transformation. Oxford, UK: IAU Press and Pergamon.

Etzkowitz, H. (1998). The norms of entrepreneurial science: Cognitive effects of the new university - industry linkages. Research Policy, $27,823-833$.
Krykunov, M. V. (Ed.). (2006). Tablytsia rozvytku misii universytetu: za materialamy John C. Scott The Mission of the University: Medieval to Postmodern Transformations. The Journal of Higher Education, 77(1). [In Ukrainian].

Mero, T. (2011). Town and gown unite. Sustainability, 4(4), 169-173.

Rishennia Kolehii MON Ukrainy. (2015). Pro ekolohizatsiiu vyshchoi osvity z metoiu pidhotovky fakhivtsiv dlia staloho rozvytku from 27.11.2015 p. Retrieved from: http://mon.gov.ua/content/Новини/2015/12/30/10-5-4.zip. [In Ukrainian].

Tunytsia, Yu. Yu., Adamovskyi, M. H., Borys, M. M., Kraievskyi, S. N., \& Mahazynshchykova, I. P. (2015). Ekolohizatsiia osvity yak kliuchovyi faktor pidhotovky fakhivtsiv dlia staloho rozvytku. Scientific Bulletin of UNFU, 25(10), 348-356. https://doi.org/10.15421/40251053

Tunytsia, Yu. Yu., Zahvoiska, L. D., \& Adamovskyi, O. M. (2016). Ekonomichnyi dyskurs osvity dlia staloho rozvytku. Higher school, 11-12, 7-27. Kyiv. [In Ukrainian].

Yu. Yu. Tunytsya, M. G. Adamovskyy, M. M. Borys, G. T. Krynytskyy

Ukrainian National Forestry University, Lviv, Ukraine

\section{UKRAINIAN NATIONAL FORESTRY UNIVERSITY - THE LEADER OF NATIONAL EDUCATION AND SCIENCE IN ACHIEVING SUSTAINABLE DEVELOPMENT GOALS}

The achievements and role of the Ukrainian National Forestry University in the field of greening of national education and science as a leading institution of higher education in providing highly qualified specialists capable of solving production and economic problems in the context of sustainable development of forestry, forest and wood processing industry. The essence and modern problems of greening higher education are considered in the light of global environmental challenges. Taking into account the 145 -year history of the University, the achievements of its staff in the training of the specialists and theoretical and applied scientific studies on topical problems of socio-ecological and economic development of Ukraine are presented, which allowed the university to become the leader of national education and science in the field of finding ways to achieve the sustainable development goals. The necessity of the World Environmenal Constitution development as an international legal act of environmental safety of the planet and sustainable development of society, the concept of which was developed by the scientists of the UNFU under the guidance of the Member of the National Academy of Sciences of Ukraine, Professor Yu. Tunytsya.

The strategy and main priority directions of research of the scientific schools formed at the university are determined, considering that the university is in a transitional stage of becoming from a model of a development university to a model of an modern entrepreneurial ecosystem university, actively integrating into the European and world higher education and science system. Based on the "Strategies and Prospects for the Development of Educational, Scientific and Innovative Activity" developed at the University the principles of fulfilling the statutory functions assigned to the University for the formation of the patriotic nationally conscious elite of Ukraine, training of highly qualified specialists for many sectors of national economy and spheres of societal life and further development of forestry education and science.

Keywords: greening of education and science; sustainable development; ecological competence; ecological-economic thinking. 